\title{
Wernisaż wystawy „Pierwsze dni Niepodległości”, Lublin 24 X 2018 r.
}

W środę 24 X 2018 r. w Auli im. Ignacego Daszyńskiego na Wydziale Politologii Uniwersytetu Marii Curie-Skłodowskiej w Lublinie odbył się wernisaż wystawy „Pierwsze dni Niepodległości”, zorganizowanej przez Muzeum Józefa Piłsudskiego w Sulejówku i Naczelną Dyrekcję Archiwów Państwowych w Warszawie, a w części poświęconej Lubelszczyźnie przez Archiwum Państwowe w Lublinie. Wystawa powstała w związku z obchodami 100-lecia niepodległości Polski. Gości, obecnych na oficjalnej części wernisażu, przywitał dyrektor Archiwum Państwowego w Lublinie dr Piotr Dymmel. Następnie głos zabrali Zdzisław Niedbała z Kancelarii Prezydenta Miasta Lublin oraz prof. dr hab. Grzegorz Nowik, kierownik Działu Historii i Badań Naukowych Muzeum Józefa Piłsudskiego w Sulejówku. Słowo do zebranych skierował również zastępca Naczelnego Dyrektora Archiwów Państwowych Ryszard Wojtkowski oraz dziekan Wydziału Politologii UMCS prof. dr hab. Iwona Hofman. Tematykę oraz koncepcję wystawy przybliżył dr Robert Jop z Archiwum Państwowego w Lublinie.

Podczas drugiej części uroczystości profesor Grzegorz Nowik wygłosił prelekcję zatytułowaną „Pierwsze dni niepodległości”, skupiając się na zagadnieniach życia codziennego w warunkach odradzającej się polskiej państwowości. Myślą przewodnią wystąpienia było docenienie wysiłków ojców niepodległości, a zwłaszcza Józefa Piłsudskiego na rzecz pokonania różnic wynikających z sytuacji politycznej i rozwoju cywilizacyjnego scalanych na powrót ziem polskich. Profesor Nowik przywołał nie tylko przykłady odmiennych rozwiązań o charakterze systemowym (np. miary i wagi), lecz także zwrócił uwagę na różnice o wiele głębsze, chociażby w sferze kultury prawnej każdego z państw zaborczych. Wykład spotkał się ze sporym zainteresowaniem słuchaczy, wśród których znalazła się liczna grupa studentów politologii UMCS. Do wystąpienia odniósł się Zdzisław Niedbała, podkreślając rolę Romana Dmowskiego w omawianych wydarzeniach. Następnie Piotr Dymmel podziękował wszystkim zaangażowanym w przygotowanie wystawy oraz uczestnikom spotkania, zachęcając jednocześnie do zapoznania się z ekspozycją. Podczas wernisażu jego uczestnicy mieli okazję obejrzeć plansze wystawy jedynie w wersji multimedialnej, co 
było spowodowane koniecznością przeniesienia spotkania do auli ze względu na panujące warunki pogodowe. Właściwa ekspozycja została umieszczona na placu Litewskim dzięki współpracy z Urzędem Miasta Lublin, który udostępnił system wystawienniczy.

Tematem wystawy były okoliczności i wydarzenia składające się na proces odzyskiwania przez Polskę niepodległości, pierwsze lata w wolnym, lecz nadal kształtującym się państwie oraz jego wewnętrzna integracja, począwszy od $1918 \mathrm{r}$. Pierwsza część ekspozycji (17 plansz) miała na celu opowiedzenie o wydarzeniach rozgrywających się w poszczególnych regionach ziem polskich, począwszy od Podhala (Zakopane) i Śląska Cieszyńskiego, poprzez obszary plebiscytowe, a skończywszy na Litwie Środkowej i Wilnie. Dzięki takiej perspektywie, przy jednoczesnym zachowaniu chronologicznego porządku zdarzeń, twórcy mogli zarysować zasięg działań niepodległościowych, doceniając rolę poszczególnych ośrodków w całym procesie. Obok dokumentacji aktowej i akcydensów na planszach znalazły się fotografie, przedstawiające pierwszoplanowe postacie tamtych wydarzeń oraz uczestników walk o Niepodległą. Archiwum Państwowe w Lublinie przygotowało część drugą (15 plansz), ukazującą etapy tworzenia się zrębów państwowości polskiej w skali regionu. Osobne plansze poświęcono administracji i sytuacji politycznej. Zaprezentowano materiały dokumentujące różne dziedziny życia mieszkańców Lubelszczyzny, w tym problemy gospodarcze i społeczne tego okresu. Nie zabrakło również treści dotyczących struktury narodowościowej i wyznaniowej regionu. Na planszach zostały odwzorowane materiały ikonograficzne, kartograficzne, aktowe oraz, najliczniej reprezentowane, druki ulotne, w tym afisze i plakaty pochodzące ze zbiorów Archiwum Państwowego w Lublinie. Wystawa „Pierwsze dni Niepodległości” była eksponowana w dniach 24 X-7 XI 2018 r. 